\title{
Strategic entrepreneurship: A management method for improving the performance of small and medium-sized tourism enterprises (SMTEs)
}

\author{
Muhanad Hasan Agha, Elena B. Gafforova
}

\begin{abstract}
With the increasing role of tourism in the global economy, many countries regard it as an effective tool for comprehensive development, a source of substantial foreign exchange revenues and a contributor to job creation. In this context, there is a growing interest in the performance and management methods of small and medium-sized tourism enterprises (SMTEs) viewed as the main component of the tourist destination. The paper examines SMTEs by studying their specificity and both external and internal factors affecting their performance. Methodologically the article relies on the theories of strategic management and entrepreneurship. It focuses on the role of a tourism destination where a tourism company operates. The article also looks at strategic entrepreneurship (SE) as a promising management method suitable for running SMTEs. The study finds that there is a certain balance between SE and the factors affecting the performance of small and medium-sized tourism enterprises. Thus, the application of SE in SMTEs enables managers and owners of such enterprises to overcome various challenges and shortcomings experienced and to exploit their resources in a way that delivers the best possible performance.
\end{abstract}

Keywords: strategic entrepreneurship; tourism; small and medium-sized business (SMTE); tourism company performance; management method.

JEL Classification: L80, L83

Paper submitted: March 20, 2019.

For citation: Hasan Agha M., Gafforova E.B. (2019). Strategic entrepreneurship: A management method for improving the performance of small and medium-sized tourism enterprises (SMTEs). Upravlenets - The Manager, vol. 10, no. 3, pp. 25-35. DOI: 10.29141/2218-5003-201910-3-3.

\section{INTRODUCTION}

Travel and tourism play a key role in the global economy. As countries increasingly open up their borders to join the wave of global integration, the development of the travel and tourism industry has become a source of substantial foreign exchange revenues for a number of economies [Giap, Gopalan, Ye, 2016]. Tourism is seen as "a ubiquitous vehicle for economic development and diversification and ... an integral element of economic development policy" [Sharpley, 2002, p. 221], and a contributor to job creation globally [Harrison, 1992a, 1992b; Brohman, 1996]. The importance of new companies in job creation, innovation, and economic change is widely recognized, and small and medium-sized tourism enterprises (SMTEs) play a significant part in assisting regional development [Harrison, Leitch, 1996; Yilmaz, 2009].

According to the World Travel \& Tourism Council (WTTC), in 2017, the direct contribution of travel and tourism was US\$2.6 trillion, and the sector offered about 119 million jobs around the world. Considering its wider indirect influences, the travel and tourism sector contributed US\$8.3 trillion to the world economy and provided nearly 313 million jobs in 2017. It represented $10.4 \%$ of the world's GDP, and arround 1 in 10 of all jobs. Over the next ten years, the direct contribution of travel and tourism to GDP is expected to grow at an average of $3.8 \%$ per year. As expected, by 2028 , the travel and tourism sector will support a total of about 414 million jobs worldwide, which equates to 1 in 9 of all jobs in the world. The sector is forecasted to provide an average of 9 million new jobs per year to 2028 (up from less than 7 million per year between 2011 and 2017), which is about one quarter of total net job creation in the world. Approximately 100 million new jobs could be created over the next decade, in case of the right regulatory conditions and government support. Meanwhile, total travel and tourism GDP is forecast to contribute $11.7 \%$ of GDP worldwide, and global visitor exports are expected to account for $6.9 \%$ of total world exports in $2028^{1}$.

The destination can be considered as the raison d'être for tourism providing a combination of tourism products, such as attractions, facilities and activities that meet the needs and desires of tourists. Moreover, destinations attract and generate the tourism trip, and consequently these are the tourism destination and its individual features that represent the most important components of a tourism product [Buhalis, Cooper, 1998].

Most tourism destinations are based upon SMTEs which provide a wide range of tourism products and services. Since a large number of SMTEs are involved in the delivery of tourism products and services, the destination is literally a blend of SMTEs that meet the needs of consumers [Buhalis, Cooper, 1998]. Othman and Rosli [2011] classify the activities of SMTEs into food and accommodation services, travel agents, retail and souvenir, transport and tour guide, and other services popular among visitors.

Unlike large tourism companies, it is increasingly difficult for SMTEs to survive and prosper in markets where competition is fierce due to their small size and the highly personalised character of their services [Keller, 2004]. Thus, SMTEs need a comprehensive management method commensurate with the specificities of companies operating in the sector, on the one hand, and with the nature of tourism and the

${ }^{1}$ The World Travel \& Tourism Council (WTTC). Travel \& Tourism Economic Impact 2018 Russian Federation. L.: WTTC. 
tourism business environment, on the other, which allows managers to make right decisions and achieve the best performance in the tourism company.

Having performed a literature review, the paper studies SMTEs by analysing the factors and characteristics affecting their performance. The research also looks at strategic entrepreneurship as an appropriate management method capable of enhancing SMTEs performance. The study aims to theoretically justify the compatibility of strategic entrepreneurship as a management method with the characteristics of SMTEs and with the factors influencing their performance.

\section{RESEARCH STRUCTURE}

This is a concept article wholly based on literature. The study focuses on exploring theoretical reasons that turn strategic entrepreneurship into an effective management method in improving SMTEs performance.

The literature review starts off with the search for strategic entrepreneurship models, characteristics of SMTEs and performance factors of tourism companies in different data bases (Scopus, Web of Science, ScienceDirect and Emerald). The publications on strategic entrepreneurship by the most renowned authors, such as Ireland, Hitt and Sirmon, are discussed and the most prominent scholars studying tourism performance, such as Buhalis and Cooper, Ritchie and Crouch, Molina-Azorin, Pereira-Moliner, Claver-Cortés are distinguished. The search also yielded results on strategic entrepreneurship models and factors that affect tourism companies' performance, as well as the importance of tourism destination for a tourism company.

The literature review shows that there is a limited number of strategic entrepreneurship models, and Ireland, Hitt and Sirmon's model [2003] is still the most used one. As for SMTEs performance, despite the seemingly endless number of factors influencing it, many authors categorize these factors into two groups - external and internal factors - which is confirmed by Molina-Azorin et al. [2009] and Fadda and Sørensen [2017].

As pointed out by Shirokova, Vega and Sokolova [2013], strategic entrepreneurship focuses on enhancing companies' performance. Since external and internal factors exert an influence on the performance of SMTEs, there arises the question whether strategic entrepreneurship as a management method is compatible with the characteristics of SMTEs and the factors affecting their performance. It is the focus of the present study.

The literature review analyses, firstly, the characters of SMTEs; secondly, the factors that determine their performance, and thirdly, the main strategic entrepreneurship model.

\section{LITERATURE REVIEW}

\section{Characteristics of SMTEs}

Classifying enterprises into different size categories is not an easy task, and the results vary from one country to another. As far as quantitative criteria are concerned, according to the Russian legislation, the criteria for classifying entities as small and medium-sized enterprises include the number of employees (no more than 250 people) and income derived from entrepreneurial activity (no more than 2 billion rubles)' When hotels are categorized, the criterion of the bed number can be applied. Most authors agree that accommodation establishments and hotels and travel agencies are considered small if they have less than 50 rooms and employ less than 10 people, respectively. In general, the vast majority of tourism enterprises worldwide can be classified as small and medium-sized businesses. More than $90 \%$ of the accommodation establishments globally are small, flexible, independent, seasonal and family-managed [Buhalis, 1996].

SMTEs are usually managed by their owners who are, in most cases, married couples running a family business [Morrison, 2002; Rashid et al., 2013]. For instance, many souvenir shops, restaurants and guesthouses are owned and staffed by the members of a single family [Buhalis, Cooper, 1998]. This is due to the fact that in the tourism industry there are numerous opportunities for SMTEs to proliferate because of the small size of start-up capital, which creates an impression that entry barriers are relatively low ${ }^{2}$. This claim is consistent with many studies conducted over the years confirming that there are opportunities for development in the tourism industry [Thomas, 2000; Hanqin, Morrison, 2007].

Clearly, the contribution of SMTEs to the tourism industry is very significant. SMTEs facilitate an infusion of tourism money into the local economy and, therefore, have a considerable beneficial influence upon the host population, which, in turn, stimulates the multiplier impacts of tourism activity in the destination. Consequently, the fortunes of both destinations and SMTEs are interrelated as the prosperity of one heavily depends upon the management and competitiveness of the other [Buhalis, Cooper, 1998].

On the other hand, SMTEs face a lot of problems and challenges. They are lack of finance, a shortage of resources [Poon, 2000; Morrison, King, 2002; Hausman, 2005] and a struggle to adopt new technologies [Drew, 2003; Gammack et al., 2004]. These characteristics prevent SMTEs from enhancing their access to the needed information and from building and developing their knowledge [Culkin, Smith, 2000].

In general, SMTEs are more vulnerable to failure, especially in their early years of operation as up to $40 \%$ of them tend to fail within the first three years and $60 \%$ close down within 10 years. Similarly, SMTEs face real survival problems because of several strategic weaknesses. Despite their unrivalled abilities to stimulate a rapid infusion of money into local economies and provide a welcome feeling for tourists, they are also characterized by a lack of strategic vision and management

\footnotetext{
${ }^{1}$ Federal Law "On Developing Small and Medium-Sized Entrepreneurship in the Russian Federation" of July 24, 2007 No. 209-FZ. Available at: http://www.consultant.ru/document/cons_doc_LAW_157188/ (in Russ.); Decree of the RF Government of April 4, 2016 No. 265“On the Marginal Values of Income Derived from Business Activities for Each Category of Small and Medium-Sized Entrepreneurship". Available at: http://www.consultant.ru/document/cons_doc_LAW_196415/ (in Russ.).

${ }^{2}$ UNESCAP (2005). Major issues in tourism development in the Asian and Pacific region: Enhancing the role of tourism in socio-economic development and poverty reduction. Available at: http://www.unescap.org.
} 
expertise, as well as an inability to utilise managerial tools in order to overcome strategic problems [Buhalis, 1996].

\section{Performance of SMTEs}

Different studies show that the performance of a tourism company is influenced by both external and internal factors [Molina-Azorin et al., 2009; Fadda, Sørensen, 2017]. Among the external factors, the tourist destination, in which a company operates, is viewed as a key factor. Hence, an attractive tourist destination is likely to maintain revenue growth rates in the tourism industry [Lerner, Haber, 2001]. On the other hand, company resources, human resource capabilities, strategy-making and entrepreneurial behaviours are some of the familiar internal elements which predetermine the competitive advantage of companies and, as a result, their performance [Barney, 1991; Lumpkin, Dess, 1996; Teece et al., 1997].

The effect of the location appears to be essentially relevant to the tourism industry because the destination where the company operates has a significant impact on its competitiveness and performance levels [Barros, 2005; Cracolici, Nijkamp, Rietveld, 2008]. The strategic importance of the tourism destination, which the company belongs to, lies in its nature that acts as a space bounding its activity and as a potential source of advantages strengthening all the companies operating within it [Camisón et al., 2016]. From the marketing viewpoint, a tourism product is an integrated experience for a tourist that is perceived and evaluated as total enjoyment in the destination [Buhalis, 1993]. Thus, a tourism destination offer is determined by a mix of products provided by various SMTEs operating in the destination, which affects the tourism experience and acts within a determined geographical parameter and generates a differentiated image [Lim, Weaver, 2014]. This approach leads to an integrated tourism development of the destination and, consequently, to the achievement of flexible specialization, synergies, system gains and scope economies for the SMTEs [Buhalis, 1993].

In spite of the importance of the external environment, the literature finds that internal factors exert a more dramatic impact on company performance [Molina-Azorin et al., 2009]. We will discuss the main internal and external factors affecting the performance of SMTEs in the following section.

\section{External Factors Affecting SMTEs Performance}

In their seeking to achieve superior performance, SMTEs should concern about the development of a tourist destination, where companies operate, through adopting appropriate strategies to enable them to contribute in this area. Many scholars emphasize the important role of SMTEs in the development of a tourism destination. One of the most cited works on the tourism is Butler's [1980] contribution to the understanding of the development of destinations [Ryan, Mottiar, Quinn, 2012].

Richard Butler [1980] considers entrepreneurial development by local residents as occurring automatically in response to growth in tourist demand [Ritchie, Crouch, 2003]. Michael Porter's [1990] model for the determinants of nation- al advantage reflects the key link between enterprise and industry competitiveness in two of the four factors which constitute his competitive "diamond": company strategy, structure and rivalry, and related and supporting industries. Porter also notes the role of chance driven by entrepreneurship: "Invention and entrepreneurship are at the heart of national advantage" [1990, p. 125]. Porter argues that the role of chance does not mean that the success of the industry is unpredictable, as entrepreneurship is not random.

Koh and Hatten clearly realize the importance of entrepreneurs in the tourism development arguing that "a community's quantity and quality of supply of entrepreneurs significantly determines the magnitude and form of its tourist-scape because the tourism entrepreneur is the persona causa of tourism development" [Koh, Hatten, 2002, p. 21]. They claim that "it is only when tourism entrepreneurs are present, do a community's climate, landforms, flora and fauna, historic vestiges, and ethno-cultural enclaves become tourism resources that may be transformed into tourist attractions" [2002, p. 27]. Without the influence of entrepreneurs, it is doubtful that the tourism industry would evolve, even in the areas that are favourably endowed with resources. McKercher [1999] clarifies, similarly, the integral part that entrepreneurs play in tourist destinations development, identifying them as "rogues or chaos makers" [1999, p. 432]. In spite of this recognition that the "innovation, flair and vision of entrepreneurs ... shaped modern tourism" [Russell, 2006 , p. 105], and the fact that "the hospitality and tourism industry has been a fertile field for entrepreneurial business" [Li, 2008, p. 1013), little has been done to offer a comprehensive understanding of the way and extent to which entrepreneurs affect tourism development [Ryan, Mottiar, Quinn, 2012].

According to Ritchie and Crouch [2003], SMTEs can contribute to the destination development by creating cooperation, competition, specialization, investment, innovation, growth, risk-taking, productivity, etc. They also mention that despite these several contributions, numerous challenges and problems are also evident. The existence of a great number of small businesses in tourism means that a lot of ownermanagers lack the experience, skills or resources to work effectively and efficiently and that "small tourism enterprises may not recognize or care about the wider and long-term consequences of some of their actions" [2003, p. 141].

Thus, in order to enhance their performance, all SMTEs operating in the tourism destination should cooperate with each other by focusing on common benefits of the destination rather than only on opportunistic objectives [Wang, Krakover, 2008; Zach, Racherla, 2011]. In their multi-level competitive analysis for SMTEs, Buhalis and Cooper [1998] point out that most entrepreneurs have focused their competitive efforts against neighbouring SMTEs and, consequently, have failed to recognize that they also compete against tourism products and services offered in substitutional destinations or even with alternative leisure activities and spending opportunities at the tourists' place of origin. They argue that the emphasis on competition within destinations should be 
reduced and local enterprises should concentrate their efforts to attract consumers, profit margins and tourists' spending from other levels of competition [Buhalis, Cooper, 1998]. Therefore, the component of products and services offered by all SMTEs operating in the destination should aim to maximise consumera' satisfaction. In this sense, SMTEs need to cooperate at the destination level in order to increase their overall competitiveness as a destination (or as the overall tourism product) against alternative tourism products which reduce their market share or profitability and, consequently, their performance [Haugland et al., 2011]. Thus, SMTEs should compete with companies in the substitute tourism destinations nationally and internationally [Buhalis, Cooper, 1998].

In the tourism literature, it is generally accepted that both the destination and individual companies can achieve gains by creating better cooperation and coordination of activities [Bramwell, Sharman, 1999; Wang, Xiang, 2007; Formica, Kothari, 2008; Pansiri, 2008]. Despite the possibility to increase companies' benefits through coordinating activities, several examples, both from tourism and other industries, indicate that it is highly difficult to establish such coordination among small, independent companies [Saxena, Ilberry, 2008]. Firstly, the companies may lack necessary managerial and financial resources to establish coordination, and managers in small companies often have Lumpkin ited time to devote to such activities. Secondly, there may be a disagreement among the companies related to the way of sharing costs and benefits, and it may be difficult to find a company willing to act as coordinator. Thirdly, companies may be reluctant to invest resources in cooperation initiatives because of their fear that other companies just want to reap the benefits while refusing to carry the costs. However, new forms of integrated, centrally managed destinations increasingly challenge such views [Beritelli, Bieger, Laesser, 2007]. Scott, Cooper, Baggio [2008] find that more industrialized destinations display higher levels of destination (interfirm) cohesion [Haugland et al., 2011].

\section{Internal Factors Affecting SMTEs Performance}

The Resource-Based View (RBV) is the most widespread theory applied to uncover the mechanisms of internal factors underlying the "company effect". The view recognizes the importance of each company's resources and capabilities in obtaining and sustaining competitive advantage [Barney, Wright, Ketchen, 2001; Amit, Schoemaker, 1993].

In order to clarify the existence of more profitable and less profitable companies within the same industry, the RBV suggests that the explanation lies in internal resources and factors of each specific company (technologies, human resources, marketing resources, culture, organization). Thus, according to this approach, it is the resources and competencies which will distinguish one company from others [Molina-Azorin et al., 2010].

The RBV considers company as a historically determined collection of assets or resources which are tied "semi-permanently" to the company [Wernerfelt, 1984]. This framework proposes that company-specific idiosyncrasies in the accu- mulation and leverage of unique and durable resources are the source of sustainable competitive advantage. Rent-producing resources determine the profitability level of companies [Molina-Azorin et al., 2010]. For profits to be sustainable, company must acquire and control valuable, rare, inimitable, and non-substitutable (VRIN) resources and capabilities [Barney, 1991].

As a complement to the RBV, the Dynamic CapabilitiesBased View (DCBV) emphasizes the strategic value of assets known as dynamic capabilities, which act as catalysts for innovation and the processes that generate and renew the company's resources and capabilities [Teece, Pisano, Shuen, 1997]. Resources are defined as tangible and intangible assets that a company either owns or controls (technology, brand names, personnel), whereas capabilities refer to ability of the company to exploit and combine resources through organizational routines with the aim of achieving its targets [Amit, Schoemaker, 1993]. Teece, Pisano and Shuen [1997] provided a comprehensive framework of dynamic capabilities that reflects a company's skill to achieve new and innovative forms of competitive advantage. These capabilities encompass organizational and managerial processes (coordination/integration, learning and reconfiguration), specific asset positions (technological, financial and reputational assets) and path dependencies (the company's history) [Molina-Azorin et al., 2010].

The RBV rests on two main assumptions. First, SMTEs may be heterogeneous with regard to the resources and capabilities on which they base their strategies. Second, these resources and capabilities may not be perfectly mobile across SMTEs, which leads to a sustainable heterogeneity among industry players [Barney, 1991].

The RBV adopted an inward-looking view dealing with companies as heterogeneous entities consisting of packages of distinctive resources [Molina-Azorin et al., 2010]. Wernerfelt [1984] advanced RBV by discussing that the internal development of resources, the nature of those resources and the different methods of employing resources have to do with profitability. In short, company heterogeneity in terms of resources and capabilities endowments can favour the achievement and maintenance of competitive advantages, which will lead to different profitability levels across SMTEs [Molina-Azorin et al., 2010].

Among the internal factors, entrepreneurial activities are also considered to be important drivers of company performance. The term "entrepreneurship" holds many different meanings and attitudes. Innovation, risk-taking and proactive inclinations are some of the more acknowledged characteristics that have been used to define entrepreneurial companies. According to the entrepreneurial orientation construct, these factors, inter alia, are regarded as necessary dimensions for defining organizations as "entrepreneurial" [Fadda, Sørensen, 2017].

Entrepreneurial orientation concerns the strategy-making process, and in this framework, only companies endowed with entrepreneurial attitudes towards making and carrying out decisions are classified as entrepreneurial [Covin, Slevin, 
1991; Miller, 1983]. It was shown that having an entrepreneurial orientation may lead to great performance. The linkage between entrepreneurial orientation and company performance has been intensely investigated, and such research has also included tourism companies [Rauch et al., 2009].

Within this complex structure, to improve the performance of SMTEs, a flexible management method should be used that enables the company to balance external and internal factors so that it can explore the surrounding opportunities and exploit the few resources owned by the SMTEs.

Strategic entrepreneurship is a relatively new recognized field built on the integration of strategic management and entrepreneurship. The modern business world requires an orientation toward strategic entrepreneurship [Shirokova, Vega, Sokolova, 2013]. Furthermore, strategic entrepreneurship is important for companies to get superior performance and to create maximum wealth [Hitt et al., 2001]. Most SMTEs are very limited in resources for the implementation of their strategies and cannot engage in various activities without confidence in obtaining positive results. A systematic idea of the implementation of strategic entrepreneurship in the company is necessary, explaining the factors that can improve the company's performance in the short and long term.

\section{STRATEGIC ENTREPRENEURSHIP}

\section{AS A PROPOSED MANAGEMENT METHOD}

The need to balance opportunity-seeking behaviour (entrepreneurship) and advantage-seeking behaviour (strategic management) represents a major management concern [Schindehutte, Morris 2009]. Successfully achieving this balance has been labelled as "Strategic Entrepreneurship (SE)" [Kyrgidou, Petridou, 2011]. The combination of strategic management and entrepreneurship has long been recognized as an important pathway for the performance and growth of the companies [Ansoff, 1965; Mintzberg, 1973; Burgelman, 1983]. Robert Burgelman indicates the need for both diversity and order, suggesting entrepreneurial activity provides such diversity; strategy provides the necessary order. Venkataraman and Sarasvathy argue that entrepreneurship and strategy are conceptually inseparable: "two sides of the same coin" [Venkataraman, Sarasvathy, 2001, p. 651] highlighting the interdependent or complementary nature of the two concepts.

Hitt et al. define SE as "the integration of entrepreneurial (i.e., opportunity-seeking actions) and strategic (i.e., advantage-seeking actions) perspectives to design and implement entrepreneurial strategies that create wealth" [Hitt et al., 2001, p. 481].

The most frequently used model of SE presented in research is the model of Ireland, Hitt and Sirmon [2003] (Fig. 1). An important distinction between this model and the previous frameworks is the conceptualization of SE as a construct. Hence, the notion of SE as both a field of study and a specific concept is reinforced and further developed therein. Also, opportunity recognition is included in Ireland et al's notion of an entrepreneurial mindset, which affects the way entrepreneurs selectively interpret and frame market signals in order to undertake entrepreneurial activity [Mitchell, Mitchell, Smith, 2008]; innovation and acceptance of risk are referred to by Ireland et al. in their discussion of entrepreneurial culture and entrepreneurial leadership. Flexibility is presented as real options logic and the notion of growth is seen as a direct outcome of Ireland et al.'s SE model. Thus, Ireland et al's development of SE provides support for the components recognized as fundamental to entrepreneurship and its intersection with strategy.

A key attribute of this model is its treatment of SE as a construct consisting of four sequential, linear and alternating entrepreneurial and strategic activities [Kyrgidou, Hughes, 2010]:

1) an entrepreneurial mindset, culture and leadership that support the search for entrepreneurial opportunity;

2) strategic management of resources that embraces managing the bundling, structuring and leverage of financial, human and social capital;

3) applying creativity to develop innovations and novel combinations to achieve radical and incremental innovation;

4) forming and executing competitive advantages.

\section{DISCUSSION}

Ireland et al's model depicts strategic entrepreneurship as a four-step linear sequence of stages by which a company alternates between episodes of entrepreneurial and strate-

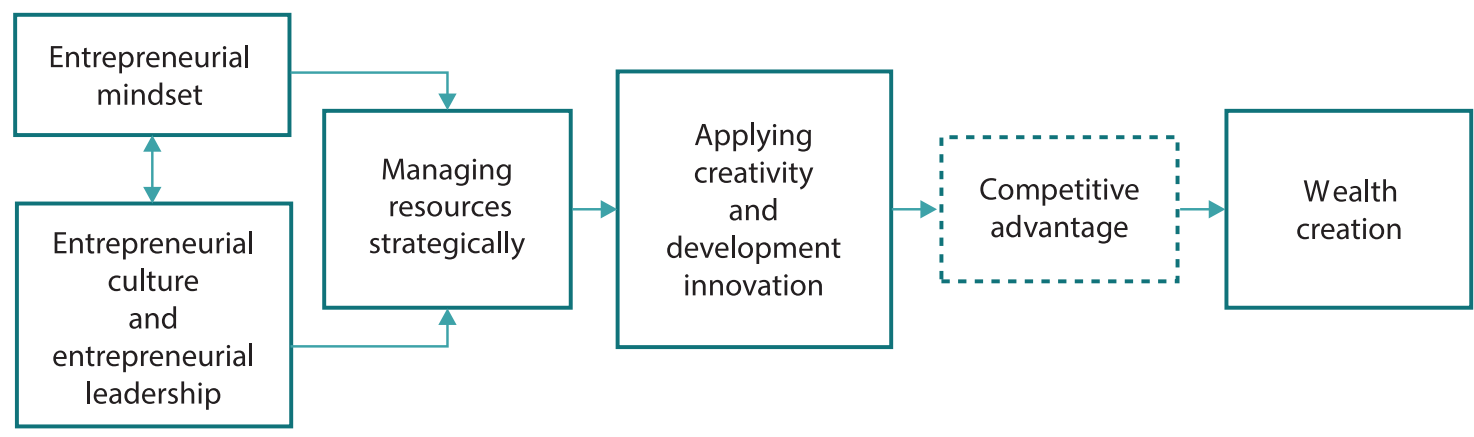

Model of strategic entrepreneurship ${ }^{1}$

Модель стратегического предпринимательства

${ }^{1}$ Source: [lreland, Hitt, Sirmon, 2003, p. 967]. 
gic behaviour in a process of strategic entrepreneurship. The effective completion of this process creates wealth.

An entrepreneurial mindset is defined as a focus on creativity and renewal capturing efforts to discover, identify and develop opportunities for new business [Ireland, Hitt, Sirmon, 2003]. This component allows a tourism company to explore new opportunities offered by the tourist destination where the company operates trying to exploit them. Managing resources strategically includes a set of actions for structuring, combining and using company's stocks of resources to form and filter those capabilities that were identified in the previous phase [Sirmon, Hitt, Ireland, 2007]. This component of SE enables the tourism company to implement appropriate cooperation strategies with other companies operating in the tourism destination, thereby contributing to the development of the destinations and gaining positive influence on the company's performance. This component also allows the tourism company to utilize its resources more efficiently, and, consequently, to offer more products using the company's resources leading to better performance for SMTEs. Bundling involves stabilising and enriching resources to form capabilities to inform the exploitation of entrepreneurial opportunities and the development of competitive advantage. Leveraging involves mobilising, coordinating and deploying resources and capabilities to capitalise on particular market opportunities [Kazanjian, Drazin, Glynn, 2000].

The innovation component represents a means by which creativity is realised and applied in the company. The act of innovating entrepreneurially can assist companies to exploit business opportunities in radical, discontinuous and disruptive ways that ultimately shift the basis of competition in the industry towards the company [Danneels 2004]. At the same time, innovations in SMTEs will contribute to the development of the tourist destination in which the company operates, which means further improvement of the company's performance. Last, the execution of competitive advantage component represents the extent to which an organisation is able to create a defendable position over its competitors by deploying current advantages in conjunction with new bundles when pursuing opportunities [Ireland, Hitt, Sirmon, 2003].

\section{CONCLUSION}

In the paper, through the analysis of scientific publications, we studied SMTEs due to the fact that they are the main component of the tourist destination, and also because this type of companies represents the majority of companies in the tourism sector. We focused on the external and internal factors that affect the performance of SMTEs considering the importance of the role played by the tourism destination in which the company operates. We then touched upon strategic entrepreneurship as a promising management method that enables managers and owners of SMTEs to overcome various challenges and shortcomings experienced by these companies and exploit their resources in a way that achieves the superior performance.

\section{References}

Amit R., Schoemaker P.J. (1993). Strategic assets and organizational rent. Strategic Management Journal, vol. 14, no. 1, pp. $33-46$. Ansoff H. (1965). Corporate Strategy. N.Y.: McGraw-Hill.

Barney J. (1991). Firm resources and sustained competitive advantage. Journal of Management, vol. 17, pp. 99-120.

Barney J., Wright M., Ketchen Jr. D.J. (2001). The resource-based view of the firm: Ten years after 1991. Journal of Management, vol. 27, no. 6, pp. 625-641.

Barros C. (2005). Measuring efficiency in the hotel sector. Annals of Tourism Research, vol. 32, pp. 456-477.

Beritelli P., Bieger T., Laesser C. (2007). Destination governance: Using corporate governance theories as a foundation for effective destination management. Journal of Travel Research, vol. 46, no. 1, pp. 96-107.

Bramwell B., Sharman A. (1999). Collaboration in local tourism policymaking. Annals of Tourism Research, vol. 26, no. 2, pp. 392-415.

Brohman J. (1996). New directions in tourism for third world development. Annals of Tourism Research, vol. 23, no. 1, pp. $48-70$.

Buhalis D. (1993). RICIRMS as a strategic tool for small and medium tourism enterprises. Tourism Management, vol. 14, no. 5, pp. 366-378.

Buhalis D. (1996). Enhancing the competitiveness of small and medium sized tourism enterprises. Electronic Markets, vol. 6, no. 1, pp. 1-6.

Buhalis D., Cooper C. (1998). Competition or co-operation? Small and medium sized tourism enterprises at the destination. In: Laws E., Faulkner B., Moscardo G. (eds.). Embracing and Managing Change in Tourism. Routledge, pp. 329-335.

Burgelman R.A. (1983). Corporate entrepreneurship and strategic management: Insights from a process study. Management Science, vol. 29, no. 12, pp. 1349-1364.

Butler R.W. (1980). The concept of a tourist area cycle of evolution: implications for management of resources. Canadian Geographer/Le Géographe Canadien, vol. 24, no. 1, pp. 5-12.

Camisón C., Puig-Denia A., Forés B., Fabra M.E., Muñoz A., Muñoz Martínez C. É. S. A. R. (2016). The importance of internal resources and capabilities and destination resources to explain firm competitive position in the Spanish tourism industry. International Journal of Tourism Research, vol. 18, no. 4, pp. 341-356.

Covin J.G., Slevin D.P. (1991). A conceptual model of entrepreneurship as firm behaviour. Entrepreneurship Theory and Practice, vol. 16, no. 1, pp. 7-26. 
Cracolici M.F., Nijkamp P., Rietveld P. (2008). Assessment of tourism competitiveness by analysing destination efficiency. Tourism Economics, vol. 14, pp. 325-342.

Culkin N., Smith D. (2000). An emotional business: a guide to understanding the motivations of small business decision takers. Qualitative Market Research: An International Journal, vol. 3, no. 3, pp. 145-157.

Danneels E. (2004). Disruptive technology reconsidered: A critique and research agenda. Journal of Product Innovation Management, vol. 21, no. 4, pp. 246-258.

Drew S. (2003). Strategic uses of e-commerce by SMEs in the east of England. European Management Journal, vol. 21, no. 1, pp. 79-88.

Fadda N., Sørensen J.F.L. (2017). The importance of destination attractiveness and entrepreneurial orientation in explaining firm performance in the Sardinian accommodation sector. International Journal of Contemporary Hospitality Management, vol. 29, no. 6, pp. 1684-1702.

Formica S., Kothari T.H. (2008). Strategic destination planning: Analyzing the future of tourism. Journal of Travel Research, vol. 46, no. 4, pp. 355-367.

Gammack J., Amaya Molinar C., Chu K., Chanpayom B. (2004). Development needs of small to medium size tourism businesses. APEC international Centre for Sustainable Tourism. Griffith University, School of Management, Nathan, Queensland.

Giap T., Gopalan S., Ye Y. (2016). Drivers of growth in the travel and tourism industry in Malaysia: A Geweke causality analysis. Economies, vol. 4, no. 3, pp. 1-15.

Hanqin Q.Z., Morrison A. (2007). How can the small to medium sized travel agents stay competitive in China's travel and service sector? International Journal of Contemporary Hospitality Management, vol. 19, no. 4, pp. 275-285.

Harrison D. (1992a). International tourism and the less developed countries: the background. In: Harrison D. (ed.). Tourism and the Less Developed Countries. L.: Belhaven. Pp. 1-18.

Harrison D. (1992b). Tourism in less developed countries: the social consequences. In: Harrison, D. (ed.). Tourism and the Less Developed Countries. L.: Belhaven. Pp. 19-34.

Harrison R., Leitch C. (1996). Whatever you hit call the target: An alternative approach to small business policy. In: Dansen M. (ed.). Small Firm Formation and Regional Economic Development. L.: Routledge. Pp. 221-247.

Haugland S.A., Ness H., Grønseth B.O., Aarstad J. (2011). Development of tourism destinations: An integrated multilevel perspective. Annals of Tourism Research, vol. 38, no. 1, pp. 268-290.

Hausman A. (2005). Innovativeness among small businesses: Theory and propositions for future research. Industrial Marketing Management, vol. 34, no. 8, pp. 773-782.

Hitt M.A., Ireland R.D., Camp S.M., Sexton D.L. (2001). Strategic entrepreneurship: Entrepreneurial strategies for wealth creation. Strategic Management Journal, vol. 22, pp. 479-491.

Ireland R.D., Hitt M.A., Sirmon D.G. (2003). A model of strategic entrepreneurship: The construct and its dimensions. Journal of Management, vol. 29, no. 6, pp. 963-989.

Kazanjian R.K., Drazin R., Glynn M.A. (2000). Creativity and technological learning: the roles of organization architecture and crisis in large-scale projects. Journal of Engineering and Technology Management, vol. 17, pp. 273-298.

Keller P. (2004). The future of small and medium enterprises in tourism. AIEST 54th Congress, pp. 1-15.

Koh K.Y., Hatten T.S. (2002). The tourism entrepreneur: The overlooked player in tourism development studies. International Journal of Hospitality \& Tourism Administration, vol. 3, no. 1, pp. 21-48.

Kyrgidou L.P., Hughes M. (2010). Strategic entrepreneurship: Origins, core elements and research directions. European Business Review, vol. 22, no. 1, pp. 43-63.

Kyrgidou L.P., Petridou E. (2011). The effect of competence exploration and competence exploitation on strategic entrepreneurship. Technology Analysis \& Strategic Management, vol. 23, no. 6, pp. 697-713.

Lerner M., Haber S. (2001). Performance factors of small tourism ventures: The interface of tourism, entrepreneurship and the environment. Journal of Business Venturing, vol. 16, no. 1, pp. 77-100.

Li L. (2008). A review of entrepreneurship research published in the hospitality and tourism management journals. Tourism Management, vol. 29, no. 5, pp. 1013-1022.

Lim Y., Weaver P.A. (2014). Customer-based brand equity for a destination: The effect of destination image on preference for products associated with a destination brand. International Journal of Tourism Research, vol. 16, no. 3, pp. $223-231$.

Lumpkin G.T., Dess G.G. (1996). Clarifying the entrepreneurial orientation construct and linking it to performance. Academy of Management Review, vol. 21, no. 1, pp. 135-172.

McKercher B. (1999). A chaos approach to tourism. Tourism Management, vol. 20, no. 4, pp. 425-434.

Miller D. (1983). The correlates of entrepreneurship in three types of firms. Management Science, vol. 29, no. 7, pp. $770-791$.

Mintzberg H. (1973). Strategy-making in three modes. California Management Review, vol. 16, no. 2, pp. 44-53.

Mitchell R.K., Mitchell J.R., Smith J.B. (2008). Inside opportunity formation: Enterprise failure, cognition, and the creation of opportunities. Strategic Entrepreneurship Journal, vol. 2, no. 3, pp. 225-242.

Molina-Azorín J.F., Claver-Cortés E., López-Gamero M.D., Tarí J.J. (2009). Green management and financial performance: A literature review. Management Decision, vol. 47, no. 7, pp. 1080-1100.

Morrison A. (2002). Small hospitality businesses: enduring or endangered? Journal of Hospitality and Tourism Management, vol. 9, no. 1, pp. 1-11.

Morrison A.J., King B.E. (2002). Small tourism businesses and e-commerce: Victorian tourism online. Tourism and Hospitality Research, vol. 4, no. 2, pp. 104-115. 


\section{Rash}

Othman P., Rosli M.M. (2011). The impact of tourism on small business performance: Empirical evidence from Malaysian islands. International Journal of Business and Social Science, vol. 2, no. 1, pp. 11-21.

Pansiri J. (2008). The effects of characteristics of partners on strategic alliance performance in the SME dominated travel sector. Tourism Management, vol. 29, no. 1, pp. 101-115.

Poon S. (2000). Small business and Internet commerce: what are the lessons learned? In: Sudaweeks F., Room C.T. (eds.). Doing Business on The Internet: Opportunities and Pitfalls. L.: Springer. Pp. 113-124.

Porter M. (1990). Competitive Strategy: Techniques for Analysing Industries and Competitors. N.Y.: Free Press.

Rashid M.M., Jaafar M., Dahalan N., Mohamed B., Bahauddin A. (2013). Tourism and SME businesses opportunity in Lenggong Valley world archaeological heritage site Malaysia. Proceedings of International Conference on Tourism Development, February 4-5, G Hotel Penang, Malaysia, pp. 150-163.

Rauch A., Wiklund J., Lumpkin G.T., Frese M. (2009). Entrepreneurial orientation and business performance: An assessment of past research and suggestions for the future. Entrepreneurship Theory and Practice, vol. 33, no. 3, pp. 761-787.

Ritchie J.B., Crouch G.I. (2003). The competitive destination: A sustainable tourism perspective. Cabi.

Russell R. (2006). The Contribution of Entrepreneurship Theory to the TALC model. In: Butler R.W. (ed.). The Tourism Area Life Cycle, vol. 2, pp. 105-124.

Ryan T., Mottiar Z., Quinn B. (2012). The dynamic role of entrepreneurs in destination development. Tourism Planning \& Development, vol. 9, no. 2, pp. 119-131.

Saxena G., Ilbery B. (2008). Integrated rural tourism a border case study. Annals of Tourism Research, vol. 35, no. 1, pp. $233-254$.

Schindehutte M., Morris M.H. (2009). Advancing strategic entrepreneurship research: The role of complexity science in shifting the paradigm. Entrepreneurship Theory and Practice, vol. 33, no. 1, pp. 241-276.

Scott N., Cooper C., Baggio R. (2008). Destination networks: Four Australian cases. Annals of Tourism Research, vol. 35, no. 1, pp. 169-188.

Sharpley R. (2002). The challenges of economic diversification through tourism: The case of Abu Dhabi. International Journal of Tourism Research, vol. 4, no. 3, pp. 221-235.

Shirokova G., Vega G., Sokolova L. (2013). Performance of Russian SMEs: Exploration, exploitation and strategic entrepreneurship. Critical Perspectives on International Business, vol. 9, no. 1/2, pp. 173-203.

Sirmon D.G., Hitt M.A., Ireland R.D. (2007). Managing firm resources in dynamic environments to create value: Looking inside the black box. Academy of Management Review, vol. 32, no. 1, pp. 273-292.

Teece D.J., Pisano G., Shuen A. (1997). Dynamic capabilities and strategic management. Strategic Management Journal, vol. 18, no. 7, pp. 509-533.

Thomas R. (2000). Small firms in the tourism industry: Some conceptual issues. International Journal of Tourism Research, vol. 2, pp. 345-353.

Venkataraman S., Sarasvathy S. (2001). Strategy and entrepreneurship: Outlines of an untold story. In: Hitt M., Freeman R., Harrison J. (ed.). The Blackwell Handbook of Strategic Management. Oxford: Blackwell. Pp. 650-668.

Wang Y., Krakover S. (2008). Destination marketing: competition, cooperation or competition? International Journal of Contemporary Hospitality Management, vol. 20, no. 2, pp. 126-141.

Wang Y., Xiang Z. (2007). Toward a theoretical framework of collaborative destination marketing. Journal of Travel Research, vol. 46, no. 1, pp. 75-85.

Wernerfelt B. (1984). A resource-based view of the firm. Strategic Management Journal, vol. 5, pp. 171-180.

Yilmaz B.S. (2009). Competitive advantage strategies for SMES: A case study in tourism sector. Management of Innovative Business \& Education Systems, vol. 3, no. 1, pp. 157-171.

Zach F., Racherla P. (2011). Assessing the value of collaborations in tourism networks: A case study of Elkhart County, Indiana. Journal of Travel \& Tourism Marketing, vol. 28, no. 1, pp. 97-110.

\section{Information about the authors}

Muhanad Hasan Agha

$\mathrm{PhD}$ Candidate in Economics. School of Economics and Management, Far Eastern Federal University (8 Sukhanova St., Vladivostok, 690091, Russia). E-mail: agha.muhanad@gmail.com.

\section{Elena B. Gafforova}

Dr. Sc. (Econ.), Associate Professor, Director of the School of Economics and Management. Far Eastern Federal University (8 Sukhanova St., Vladivostok, 690091, Russia). E-mail: gafforova.eb@dvfu.ru. 


\title{
Стратегическое предпринимательство: управленческий метод для повышения результативности малых и средних компаний в сфере туризма
}

\author{
М. Хасан Ага, Е.Б. Гаффорова
}

Аннотация. Возрастающая роль индустрии туризма в мировой экономике позволяет все большему числу стран рассматривать
ее не только как эффективный инструмент всестороннего развития, но и как источник значительных валютных поступлений
и создания рабочих мест. Статья посвящена исследованию управленческих методов и эффективности функцинирования
малых и средних туристических компаний (МстК), являющихся основными акторами туристического рынка. Методологический
базис исследования составляют теории стратегического менеджмента и предпринимательства. На основе анализа актуальных
научных источников выделены внешние и внутренние факторы, влияющие на результативность деятельности МстК. Особое
внимание уделяется туристическому направлению и его важности для эффективного функционирования таких фирм. В рам-
ках исследования стратегическое предпринимательство рассматривается как перспективный метод управления малыми
и средними туристическими компаниями. Выявлена гармоничная связь между стратегическим предпринимательством
и факторами, воздействующими на результативность деятельности МстК. Авторы приходят к выводу, что применение постулатов
стратегического предпринимательства при управлении МстК позволяет менеджерам и владельцам этих компаний повысить
эффективность ведения бизнеса и оптимизировать использование доступных ресурсов для достижения наилучших результатов. Ключевые слова: стратегическое предпринимательство; туризм; малые и средние предприятия; результаты деятельности туристической компании; управленческий метод.

JEL Classification: L80, L83

Аата поступиения статьи: 20 марта 2019 г.

Ссылка для цитирования: Хасан Ага М., Гаффорова Е.Б. Стратегическое предпринимательство: управленческий метод для повышения результативности малых и средних компаний в сфере туризма // Управленец. 2019. Т. 10. №3. С. 25-35. DOI: 10.29141/22185003-2019-10-3-3.

\section{Источники}

Amit R., Schoemaker P.J. (1993). Strategic assets and organizational rent. Strategic Management Journal, vol. 14, no. 1, pp. 33-46. Ansoff H. (1965). Corporate Strategy. N.Y.: McGraw-Hill.

Barney J. (1991). Firm resources and sustained competitive advantage. Journal of Management, vol. 17, pp. 99-120.

Barney J., Wright M., Ketchen Jr. D.J. (2001). The resource-based view of the firm: Ten years after 1991. Journal of Management, vol. 27, no. 6, pp. 625-641.

Barros C. (2005). Measuring efficiency in the hotel sector. Annals of Tourism Research, vol. 32, pp. 456-477.

Beritelli P., Bieger T., Laesser C. (2007). Destination governance: Using corporate governance theories as a foundation for effective destination management. Journal of Travel Research, vol. 46, no. 1, pp. 96-107.

Bramwell B., Sharman A. (1999). Collaboration in local tourism policymaking. Annals of Tourism Research, vol. 26, no. 2, pp. $392-415$. Brohman J. (1996). New directions in tourism for third world development. Annals of Tourism Research, vol. 23, no. 1, pp. 48-70.

Buhalis D. (1993). RICIRMS as a strategic tool for small and medium tourism enterprises. Tourism Management, vol. 14, no. 5, pp. 366-378.

Buhalis D. (1996). Enhancing the competitiveness of small and medium sized tourism enterprises. Electronic Markets, vol. 6, no. 1, pp. 1-6.

Buhalis D., Cooper C. (1998). Competition or co-operation? Small and medium sized tourism enterprises at the destination. In: Laws E., Faulkner B., Moscardo G. (eds.). Embracing and Managing Change in Tourism. Routledge, pp. 329-335.

Burgelman R.A. (1983). Corporate entrepreneurship and strategic management: Insights from a process study. Management Science, vol. 29, no. 12, pp. 1349-1364.

Butler R.W. (1980). The concept of a tourist area cycle of evolution: implications for management of resources. Canadian Geographer/ Le Géographe Canadien, vol. 24, no. 1, pp. 5-12.

Camisón C., Puig-Denia A., Forés B., Fabra M.E., Muñoz A., Muñoz Martínez C. É. S. A. R. (2016). The importance of internal resources and capabilities and destination resources to explain firm competitive position in the Spanish tourism industry. International Journal of Tourism Research, vol. 18, no. 4, pp. 341-356.

Covin J.G., Slevin D.P. (1991). A conceptual model of entrepreneurship as firm behaviour. Entrepreneurship Theory and Practice, vol. 16, no. 1, pp. 7-26.

Cracolici M.F., Nijkamp P., Rietveld P. (2008). Assessment of tourism competitiveness by analysing destination efficiency. Tourism Economics, vol. 14, pp. 325-342.

Culkin N., Smith D. (2000). An emotional business: a guide to understanding the motivations of small business decision takers. Qualitative Market Research: An International Journal, vol. 3, no. 3, pp. 145-157.

Danneels E. (2004). Disruptive technology reconsidered: A critique and research agenda. Journal of Product Innovation Management, vol. 21, no. 4, pp. 246-258.

Drew S. (2003). Strategic uses of e-commerce by SMEs in the east of England. European Management Journal, vol. 21, no. 1, pp. 79-88.

Fadda N., Sørensen J.F.L. (2017). The importance of destination attractiveness and entrepreneurial orientation in explaining firm performance in the Sardinian accommodation sector. International Journal of Contemporary Hospitality Management, vol. 29 , no. 6, pp. 1684-1702.

Formica S., Kothari T.H. (2008). Strategic destination planning: Analyzing the future of tourism. Journal of Travel Research, vol. 46, no. 4, pp. 355-367. 
Gammack J., Amaya Molinar C., Chu K., Chanpayom B. (2004). Development needs of small to medium size tourism businesses. APEC international Centre for Sustainable Tourism. Griffith University, School of Management, Nathan, Queensland.

Giap T., Gopalan S., Ye Y. (2016). Drivers of growth in the travel and tourism industry in Malaysia: A Geweke causality analysis. Economies, vol. 4, no. 3, pp. 1-15.

Hanqin Q.Z., Morrison A. (2007). How can the small to medium sized travel agents stay competitive in China's travel and service sector? International Journal of Contemporary Hospitality Management, vol. 19, no. 4, pp. 275-285.

Harrison D. (1992a). International tourism and the less developed countries: the background. In: Harrison D. (ed.). Tourism and the Less Developed Countries. L.: Belhaven. Pp. 1-18.

Harrison D. (1992b). Tourism in less developed countries: the social consequences. In: Harrison, D. (ed.). Tourism and the Less Developed Countries. L.: Belhaven. Pp. 19-34.

Harrison R., Leitch C. (1996). Whatever you hit call the target: An alternative approach to small business policy. In: Dansen M. (ed.). Small Firm Formation and Regional Economic Development. L.: Routledge. Pp. 221-247.

Haugland S.A., Ness H., Grønseth B.O., Aarstad J. (2011). Development of tourism destinations: An integrated multilevel perspective. Annals of Tourism Research, vol. 38, no. 1, pp. 268-290.

Hausman A. (2005). Innovativeness among small businesses: Theory and propositions for future research. Industrial Marketing Management, vol. 34, no. 8, pp. 773-782.

Hitt M.A., Ireland R.D., Camp S.M., Sexton D.L. (2001). Strategic entrepreneurship: Entrepreneurial strategies for wealth creation. Strategic Management Journal, vol. 22, pp. 479-491.

Ireland R.D., Hitt M.A., Sirmon D.G. (2003). A model of strategic entrepreneurship: The construct and its dimensions. Journal of Management, vol. 29, no. 6, pp. 963-989.

Kazanjian R.K., Drazin R., Glynn M.A. (2000). Creativity and technological learning: the roles of organization architecture and crisis in large-scale projects. Journal of Engineering and Technology Management, vol. 17, pp. 273-298.

Keller P. (2004). The future of small and medium enterprises in tourism. AIEST 54th Congress, pp. 1-15.

Koh K.Y., Hatten T.S. (2002). The tourism entrepreneur: The overlooked player in tourism development studies. International Journal of Hospitality \& Tourism Administration, vol. 3, no. 1, pp. 21-48.

Kyrgidou L.P., Hughes M. (2010). Strategic entrepreneurship: Origins, core elements and research directions. European Business Review, vol. 22, no. 1, pp. 43-63.

Kyrgidou L.P., Petridou E. (2011). The effect of competence exploration and competence exploitation on strategic entrepreneurship. Technology Analysis \& Strategic Management, vol. 23, no. 6, pp. 697-713.

Lerner M., Haber S. (2001). Performance factors of small tourism ventures: The interface of tourism, entrepreneurship and the environment. Journal of Business Venturing, vol. 16, no. 1, pp. 77-100.

Li L. (2008). A review of entrepreneurship research published in the hospitality and tourism management journals. Tourism Management, vol. 29, no. 5, pp. 1013-1022.

Lim Y., Weaver P.A. (2014). Customer-based brand equity for a destination: The effect of destination image on preference for products associated with a destination brand. International Journal of Tourism Research, vol. 16, no. 3, pp. 223-231.

Lumpkin G.T., Dess G.G. (1996). Clarifying the entrepreneurial orientation construct and linking it to performance. Academy of Management Review, vol. 21, no. 1, pp. 135-172.

McKercher B. (1999). A chaos approach to tourism. Tourism Management, vol. 20, no. 4, pp. 425-434.

Miller D. (1983). The correlates of entrepreneurship in three types of firms. Management Science, vol. 29, no. 7, pp. $770-791$.

Mintzberg H. (1973). Strategy-making in three modes. California Management Review, vol. 16, no. 2, pp. 44-53.

Mitchell R.K., Mitchell J.R., Smith J.B. (2008). Inside opportunity formation: Enterprise failure, cognition, and the creation of opportunities. Strategic Entrepreneurship Journal, vol. 2, no. 3, pp. 225-242.

Molina-Azorín J.F., Claver-Cortés E., López-Gamero M.D., Tarí J.J. (2009). Green management and financial performance: A literature review. Management Decision, vol. 47, no. 7, pp. 1080-1100.

Morrison A. (2002). Small hospitality businesses: enduring or endangered? Journal of Hospitality and Tourism Management, vol. 9 , no. 1, pp. 1-11.

Morrison A.J., King B.E. (2002). Small tourism businesses and e-commerce: Victorian tourism online. Tourism and Hospitality Research, vol. 4, no. 2, pp. 104-115.

Othman P., Rosli M.M. (2011). The impact of tourism on small business performance: Empirical evidence from Malaysian islands. International Journal of Business and Social Science, vol. 2, no. 1, pp. 11-21.

Pansiri J. (2008). The effects of characteristics of partners on strategic alliance performance in the SME dominated travel sector. Tourism Management, vol. 29, no. 1, pp. 101-115.

Poon S. (2000). Small business and Internet commerce: what are the lessons learned? In: Sudaweeks F., Room C.T. (eds.). Doing Business on The Internet: Opportunities and Pitfalls. L.: Springer. Pp. 113-124.

Porter M. (1990). Competitive Strategy: Techniques for Analysing Industries and Competitors. N.Y.: Free Press.

Rashid M.M., Jaafar M., Dahalan N., Mohamed B., Bahauddin A. (2013). Tourism and SME businesses opportunity in Lenggong Valley world archaeological heritage site Malaysia. Proceedings of International Conference on Tourism Development, February 4-5, G Hotel Penang, Malaysia, pp. 150-163.

Rauch A., Wiklund J., Lumpkin G.T., Frese M. (2009). Entrepreneurial orientation and business performance: An assessment of past research and suggestions for the future. Entrepreneurship Theory and Practice, vol. 33, no. 3, pp. 761-787.

Ritchie J.B., Crouch G.I. (2003). The competitive destination: A sustainable tourism perspective. Cabi.

Russell R. (2006). The Contribution of Entrepreneurship Theory to the TALC model. In: Butler R.W. (ed.). The Tourism Area Life Cycle, vol. 2, pp. 105-124.

Ryan T., Mottiar Z., Quinn B. (2012). The dynamic role of entrepreneurs in destination development. Tourism Planning \& Development, vol. 9, no. 2, pp. 119-131.

Saxena G., Ilbery B. (2008). Integrated rural tourism a border case study. Annals of Tourism Research, vol. 35, no. 1, pp. $233-254$. 
Schindehutte M., Morris M.H. (2009). Advancing strategic entrepreneurship research: The role of complexity science in shifting the paradigm. Entrepreneurship Theory and Practice, vol. 33, no. 1, pp. 241-276.

Scott N., Cooper C., Baggio R. (2008). Destination networks: Four Australian cases. Annals of Tourism Research, vol. 35, no. 1, pp. 169-188.

Sharpley R. (2002). The challenges of economic diversification through tourism: The case of Abu Dhabi. International Journal of Tourism Research, vol. 4, no. 3, pp. 221-235.

Shirokova G., Vega G., Sokolova L. (2013). Performance of Russian SMEs: Exploration, exploitation and strategic entrepreneurship. Critical Perspectives on International Business, vol. 9, no. 1/2, pp. 173-203.

Sirmon D.G., Hitt M.A., Ireland R.D. (2007). Managing firm resources in dynamic environments to create value: Looking inside the black box. Academy of Management Review, vol. 32, no. 1, pp. 273-292.

Teece D.J., Pisano G., Shuen A. (1997). Dynamic capabilities and strategic management. Strategic Management Journal, vol. 18, no. 7, pp. 509-533.

Thomas R. (2000). Small firms in the tourism industry: Some conceptual issues. International Journal of Tourism Research, vol. 2, pp. 345-353.

Venkataraman S., Sarasvathy S. (2001). Strategy and entrepreneurship: Outlines of an untold story. In: Hitt M., Freeman R., Harrison J. (ed.). The Blackwell Handbook of Strategic Management. Oxford: Blackwell. Pp. 650-668.

Wang Y., Krakover S. (2008). Destination marketing: competition, cooperation or competition? International Journal of Contemporary Hospitality Management, vol. 20, no. 2, pp. 126-141.

Wang Y., Xiang Z. (2007). Toward a theoretical framework of collaborative destination marketing. Journal of Travel Research, vol. 46, no. 1 , pp. 75-85.

Wernerfelt B. (1984). A resource-based view of the firm. Strategic Management Journal, vol. 5, pp. 171-180.

Yilmaz B.S. (2009). Competitive advantage strategies for SMES: A case study in tourism sector. Management of Innovative Business \& Education Systems, vol. 3, no. 1, pp. 157-171.

Zach F., Racherla P. (2011). Assessing the value of collaborations in tourism networks: A case study of Elkhart County, Indiana. Journal of Travel \& Tourism Marketing, vol. 28, no. 1, pp. 97-110.

\section{Информация об авторах}

\section{ХАСАН АГА МуханаА}

Аспирант Школы экономики и менеАжмента. Аальневосточный федеральный университет (690091, РФ, г. Владивосток, ул. Суханова, 8). E-mail: agha.muhanad@gmail.com.

\section{ГАФФОРОВА Елена Борисовна}

Аоктор экономических наук, Аоцент, Аиректор Школы экономики и менеАжмента. Аальневосточный федеральный университет (690091, РФ, г. Владивосток, ул. Суханова, 8). E-mail: gafforova.eb@dvfu.ru. 